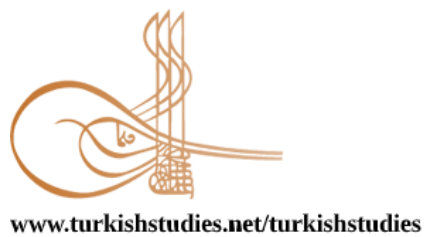

Turkish Studies

\title{
Covid-19 Küresel Salgında Dünyada ve Türkiye'de Uygulanan Ekonomi Politikaları Üzerine Bir Değerlendirme
}

\author{
An Evaluation on Economic Policies Applied in the World and Turkey in Covid-19 Global \\ Outbreak
}

\author{
Savaş Durmuş* - Dilek Şahin ${ }^{* *}$
}

\begin{abstract}
Undoubtedly, Covid-19 disease will be at the top of the events that marked the 21 st century. Covid19 is the one of the highest risk of death, leaving behind other diseases with high transmission rate and speed among the epidemics seen in the world through out history. The Covid-19 disease that emerged in China has spread to more than 170 countries globally today. Based on the data that the number of sovereign countries, which are members of the United Nations in the world, is 195, the fact that the spread of the disease to the world countries is more than $87 \%$. Similarly, considering that the total population of the World countries is 7.6 billion and the number of cases is 6.5 million, it is revealed that the transmission rate of the disease among people is more than $8.5 \%$. Due to this spreading and contagious feature, Covid-19 has been declared as a pandemic by the World Health Organization and is in the category of pandemic diseases. The negative effect of pandemic is not only limited to the health sector, but also created a panic atmosphere on both people and states. It is extremely important to protect the economy as well as the health along with the global epidemic and to fight the epidemic without further damage to the economy. From this point of view, the economic and financial measures taken / to be taken by the world countries are very important. Countries should use their monetary and fiscal policies in the most rational way, especially in this process, where the epidemic process continues. In this study, information is presented about Covid-19 and its possible effects on the both world and Turkey economy and the current economic policies during this pandemic.
\end{abstract}

Structured Abstract: The Covid-19 outbreak poses a serious health threat to the world, but it also affects economies significantly. Measures taken to prevent the spread of the outbreak on the one hand, it negatively affects individual consumption habits, on the other hand, production processes and employment. In order to prevent the spread of the epidemic and to cope with its effects, it is seen that policy makers use various practices all over the world. On the one hand, Central Banks take steps to provide liquidity, on the other hand, measures have been taken to support households and firms most affected by the fiscal policies and the epidemic.

\footnotetext{
* Dr. Öğr. Üyesi, Kafkas Üniversitesi İktisadi ve İdari Bilimler Fakültesi, Uluslararası Ticaret ve Lojistik Bölümü

Assistant Prof. Dr., Kafkas University Faculty of Economics and Administrative Sciences, Department of International Trade and Logistics

** Doç. Dr, Sivas Cumhuriyet Üniversitesi, Turizm Fakültesi, Turizm İşletmeciliği Bölümü

Associate Professor, Sivas Cumhuriyet University Faculty of Tourism, Department of Tourism Management ORCID 00000-0002-4830-8106

dilek58sahin@hotmail.com

Cite as/ Atıf: Durmuş, S. \& Şahin, D. (2020). Covid-19 Küresel Salgında Dünyada ve Türkiye'de Uygulanan Ekonomi Politikaları Üzerine Bir Değerlendirme, Turkish Studies, 15(4), 923-943. https://dx.doi.org/10.7827/TurkishStudies.44506

Received/Geliş: 24 June/Haziran 2020

Accepted/Kabul: 27 August/Ağustos 2020

Copyright (C) MDE, Turkey

Checked by plagiarism software Published/Yayın: 30 August/Ağustos 2020 CC BY-NC 4.0
} 
The problems caused by the coronavirus outbreak differ from the classical economic crises. In classical recession situations, problems arise on the demand front compared to supply. However, with the effect of the epidemic on the one hand, while the demand falls, on the other hand, problems arise on the supply front. Although coronavirus seems to affect almost every sector differently, the sector most affected by the epidemic has received airline companies. Due to the closing of the borders of many countries or the restrictions on travel, tourism and travel sectors are among the sectors that experienced the first negative impact. In addition, the oil and natural gas, automotive, consumer goods, electronics and semiconductor sectors lead the sectors that are negatively affected. In China, which has a dynamic role in the world economy, the shocks in the productionsupply and marketing chain negatively affected all the world economies. The logistic activities coming to a halt among the countries caused panic in the financial markets. Pandemic has changed the economic balances of developing countries. The liquidity shortage and exchange rate pressure in these countries caused the balance in financial markets to deteriorate. In the developing countries with dense capital inflows, foreign capital inflows have stopped completely and even capital outflows have accelerated.

While exports declined drastically, decreases and fluctuations in raw material and oil prices shook foreign trade deeply. These negativities led to the depreciation of stocks in the developing countries, a rapid exit from the stock markets and sales of bonds and bills. At the same time, the dollarization effect experienced in developing countries caused the local currencies of these countries to lose value against the dollar. Among these countries, particularly Mexico, Russia, Brazil, Africa, and Turkey it is possible to sort out. The panic that has been experienced has led world countries to see gold as a safe haven and turn to US bonds.

If enough public health measures are not taken to control the spread of the disease and alleviate its effects, pain and losses in human life can lead to disaster. Accordingly, income losses can also be large. In addition, measures to control and reduce by slowing down economic activity can worsen income losses associated with pandemics. For the economy, a shock as strong as Covid-19 stands for stagnation. High mortality rates and disease rates cause a decrease in labor, production capacity and productivity (supply shock). The increase in uncertainty and decrease in wealth cause a decrease in consumption and investment (demand shock). Under a global crisis, the situation is getting worse because negative supply and demand shocks are transferred to all countries through trade, finance and immigration links. In developing countries, vulnerability to pandemics is higher and the ability to cope with policy is lower than in developed countries. In addition to direct effects, Covid-19 brings a sharp foreign demand shock for developing countries that are exposed to global conditions. This is extremely important, for example, in East Asian countries, where commerce and tourism is a major part of the economy, for developing countries, where the export of goods is heavily in public revenues and is heavily dependent on labor exchange from developed countries.

Economic administrations in the world have developed solution methods to limit the effects of coronavirus and to combat the epidemic. In this context, the Federal Reserve went to an interest rate cut in March and dropped the policy rate to $0-0.25 \%$. Central banks, including Turkey remained the same applications found. In addition to the measures taken by the Central Banks, governments have started to announce incentive packages in order to activate the economy. Necessary measures have been taken to provide the cash support needed for the incentive package that will increase individual spending and demand. Loan incentive packages are provided to cover the fixed expenses of the consumers staying in the houses and to allow them to spend. On the other hand, various incentives such as salary assistance, tax reduction, increasing credit limits and postponing debts were provided to companies whose default risk was increased, while supports for the tourism and aviation sector came to the fore.

Fiscal policy practices have been used as sizeable complementary automatic stabilizers in some countries. The amount of measures on the budget has been changed significantly, G-20 countries have declared $1.6 \%$ of GDP as non-cash income and expenditure measures. Aid packages; credit programs, guarantees, debt cancellation, subsidies to help companies suffering from cash flow shortages and maintain business, transfer expenditures for individuals, unemployment insurance and welfare systems developed to ensure that people have sufficient income to meet their basic needs. Developed countries have launched major health and public spending programs against the economic effects of the Covid-19 outbreak. The financial and monetary responses of low-income countries have been more limited and ideas for the roles they will play in the aid of international organizations have been discussed. Most developed countries have reacted greatly to the Covid19 outbreak and increased spending and monetary policy to alleviate the effects that led to the closure of businesses and the increase in the number of unemployed people. Relatively limited financial support has been

Turkish Studies, 15(4) 
provided in emerging markets and emerging economies. In the Covid-19 process, central banks also quickly took action. In this context, central banks significantly loosened their monetary policy with practices that included lowering policy rates and, in some cases, extending asset purchases to put downward pressure on long-term interest rates.

Like all countries in the world it was caught unprepared by the pandemic process in Turkey. Measures taken in order to relieve Turkey's economy has rapidly by activating the economy, water can be described. As in other countries of the world in the medical health field has given priority to measures previously in Turkey. Turkey has given priority to the health measures in the fight against the pandemic. In the economic sense, the negative effects of the pandemic process started to be reduced with the monetary policies, and then continued with the fiscal policy. The process, which continued with direct income transfer mechanisms in April, continued with the interest rate cut in May. In Turkey, employees in the service sector has been the most adversely affected in this process. The scope of the corona virus-related development to limit the adverse effects on Turkey's economy; With the Monetary Policy Committee meeting held on March 17, 2020, the Bank reduced its policy rate by 100 basis points to $9.75 \%$ with the aim of ensuring a sound continuity of financial markets, credit channels and firms. Due to the coronavirus epidemic, a difficult period has been entered due to both demand and supply affecting the economy. In this context, in order to limit the negative effects of the coronavirus epidemic and reduce the negative effects of the experienced process on the economy, the market, production and employment, a package set of 100 billion lira was put into service on 18 March 2020.

Keywords: Macroeconomy, Monetary and Fiscal Policy, Covid-19, World, Turkey.

Öz: 21. Yüzyıla damgasına vuran olayların başında şüphesiz Covid-19 salgını yer alacaktır. Tarih boyunca Dünya üzerinde görülen salgın hastalıklar içerisinde bulaşma oranı ve hızı yüksek olan diğer hastalıkları geride bırakan Covid-19, ölüm riski en yüksek olanıdır. Çin'de ortaya çıkan Covid-19 hastalığı bugün küresel anlamda 170 'den fazla ülkeye sirayet etmiştir. Dünya üzerinde Birleşmiş Milletlere üye olan egemen ülke sayısının 195 olduğu verisinden hareket edildiğinde hastalığın dünya ülkelerine yayılma oranının $\% 87$ 'den daha fazla olduğu gerçeği ortaya çıkmaktadır. Benzer şekilde, dünya ülkelerinin toplam nüfusunun 7,6 milyar, vaka sayısının ise 6,5 milyon olduğu dikkate alındığında hastalığın insanlar arasında bulaşma oranın \% 8,5'dan daha fazla olduğu ortaya çıkmaktadır. Bu yayılma ve bulaşıcılık özelliğinden ötürü Covid-19, Dünya Sağlık Örgütü tarafindan, pandemi olarak ilan edilmiş ve pandemik hastalıklar kategorisinde yer almıştır. Pandemi'nin oluşturduğu negatif etki sadece sağlık sektörü ile sınırlı kalmayıp, hem insanlar hem de ülkeler üzerinde bir panik havası oluşturdu. Küresel salgınla birlikte sağlığın olduğu kadar, ekonominin de korunması ve salgınla ekonomiye daha fazla zarar vermeden mücadele edilmesi son derecede önemlidir. Bu açıdan (hareketle) dünya ülkelerinin aldıkları/alacakları ekonomik ve finansal tedbirler oldukça önem arz etmektedir. Özellikle salgın sürecinin devam ettiği bu süreçte ülkeler para ve maliye politikalarını en rasyonel şekilde kullanması gerekmektedir. Bu kısım eklenebilir. Bu çalışmada, Covid-19 küresel salgınının dünya ve Türkiye ekonomisi üzerindeki olası etkisi ve bu dönemde uygulanan ekonomi politikaları hakkında bilgi verilmiştir.

Anahtar Kelimeler: Makroekonomi, Para ve Maliye Politikası, Covid-19, Dünya, Türkiye.

\section{Giriş}

21. yüzyıla damgasına vuran olayların başında şüphesiz Covid-19 hastalığı yer alacaktır. Hastalık bulaşıcılık oranı ve hızı yüksek olan diğer hastalıkları geride bırakarak, ölüm riski yüksek hastalıklar içerisinde birinci sıraya yükselmiştir. Dünya Sağlık Örgütü (WHO) verilerine göre dünya üzerinde vaka sayısının 6.5 milyona ulaştığı, 383 bin insanın hayatını kaybettiği ve salgının 170'den fazla ülkede varlığ tespit edilmiştir (WHO, 2020:1; Düşündere ve Dündar, 2020:1). Bu tehlikeli durum karşısında Dünya Sağlık Örgütü 11 Mart 2020 tarihinde "Pandemi" ilan etmiştir. Pandemi tıp terminolojisinde kullanılan bir terim olup anlam olarak dünya ülkelerinin büyük bir çoğunluğunda insanların sağlığını tehdit eden bulaşıcı hastalı̆̆ı ifade etmektedir (Türkiye Bilimler Akademisi, 2020: 20). Koronavirüs ile mücadele kapsamında sağlik sisteminin mevcut kapasitesini aşmaması için çoğu ülkede sıkı sosyal mesafe önlemleri uygulanmaya başlamıştır. Bu önlemler kapsamında 
başta hizmet sektörü olmak üzere havayolu taşımacılığı, turizm, konaklama gibi çok sayıda sektör etkilenmiştir. Yine serbest meslek ve işyeri sahipleri de koronavirüs salgının ortaya çıkardığ krizden etkilenenler arasında yer almaktadır. Virüsün etki alanı genişledikçe salgının ekonomik boyutu da kendini hissettirmeye başlamıştır. Covid-19'dan sağlığın olduğu kadar ekonominin koruması, salgınla ekonomiye daha fazla zarar vermeden mücadele etmenin yolları bulunmalıdır. Çünkü sağlığı korumak ekonomiyi korumak, ekonomiyi korumak sağlığı korumaktır.

Covid-19 salgını, tüm dünya için ciddi bir sağlık tehdidi oluşturmakla birlikte ekonomileri de önemli ölçüde etkilemektedir. Salgının yayılmasını önlemek amacıyla alınan tedbirler bir yandan bireysel tüketim alışkanlıklarını, diğer yandan üretim süreçlerini ve istihdamı olumsuz etkilemektedir. Salgının yayılmasını önlemek ve etkileriyle baş edebilmek için tüm dünyada politika yapıcıların çeşitli uygulamalara başvurdukları görülmektedir. Bir yandan Merkez Bankaları likidite sağlama adımları atarken diğer yandan maliye politikaları ile salgından en fazla etkilenen hane halkı ve firmaların desteklenmesi için önlemler alınmaya başlanmıştır. Özellikle Merkez Bankaları tarafından koronavirüs salgınının etkilerine karşı alınan tedbirler, bankacılık sektörüne ve reel sektöre ihtiyaç duydukları likiditeyi uygun koşullarla sağlamak amacı taşımaktadır. Bu çalışmada, Covid-19 küresel salgınının dünya ve Türkiye ekonomisi üzerindeki etkisi ve bu dönemde uygulanan ekonomi politikaları hakkında bilgi verilmiştir. Çalışma teorik olup şu şekilde organize edilmiştir. Giriş bölümünün ardından Covid-19 salgını ve küresel ekonomiden bahsedilmiştir. Ardından, dünyada Covid-19 salgınına karşı alınan önlemler ele alınmıştır. Daha sonra Türkiye'de Covid-19 sürecinde uygulanan para ve maliye politikalarına değinilmiştir. Çalışma sonuç bölümü ile tamamlanmıştır.

\section{Covid-19 Salgını ve Küresel Ekonomi}

Dünyanın en önemli tarım ve sanayi ülkelerinin başında Çin yer almaktadır. Dünya ticaretinde önemli bir role sahip olan Çin'de hastalığın ortaya çıkışı ve ilk vakanın tespiti 2019 yılının Aralık ayına denk gelmektedir (Türkiye Bilimler Akademisi, 2020: 29).Çin'in Wuhan şehrinde ortaya çıkan ilk vaka 15 Şubat 2020 tarihinden itibaren diğer dünya ülkelerine de yayılmıştır. Dünya Sağlık Örgütü, koronavirüsün toplum sağlığını etkilediğini resmi olarak ilk kez 30 Ocak 2020 tarihinde duyurmuş ve 11 Mart 2020 tarihinde de dünya genelinde pandemi ilan etmiştir. Pandemi, dünyada birden fazla ülkede veya kıtada geniş bir alana yayılan ve etkisini gösteren salgın hastalıklara verilen isimdir. Salgının pandemi ilan edilmesinde hastalığın ölümcül olması, bulaşıcılığının devam etmesi ve birden fazla ülkeye yayılması kriterleri göz önünde bulundurulmuştur.

Koronavirüs salgının ortaya çıkardığı sorunlar, klasik ekonomik krizlerden farklılık göstermektedir. Klasik resesyon durumlarında arza kıyasla talep cephesinde sıkıntılar baş gösterir. Hâlbuki yaşanan salgının etkisiyle bir yandan talep düşerken diğer yandan arz cephesinde de sıkıntılar ortaya çıkmaktadır. İşletmelerin kapalı olması, firma personelinin evde kalması mal ve hizmet üretiminin önünde bulunan en önemli engellerden biridir. Bu süreçte, AVM'ler kapanma kararı almış özellikle tüketici ile yüz yüze temas kuran hizmet sektörleri önemli ölçüde sıkıntılar yaşamaya başlamıştır. Ayrıca yaşanan güvensizlik ve belirsizlik ortamının harcama gruplarının tüketim eğilimlerinin düşmesine neden olmuştur.

Korona virüsün hemen her sektörü farklı ölçüde etkilediği görülmekle birlikte salgından en fazla etkilenen sektör hava yolu şirketleri almıştır. Çok sayıda ülkenin sınırlarını kapatması veya seyahate kısitlamalar getirilmesinin etkisiyle, turizm ve seyahat sektörleri ilk olumsuz etkiyi yaşayan sektörlerin başında gelmektedir. Bunun yanı sıra, petrol ve doğalgaz, otomotiv, tüketim ürünleri, elektronik ve yarı-iletken sektörleri de olumsuz etkilenen sektörlerin başını çekmektedir.

Korona virüsün neden olduğu kriz, dünya ekonomisini İkinci Dünya Savaşından bu yana bilinmeyen bir noktaya sürüklemekle birlikte söz konusu kriz, sadece insan sağlı̆̆ını bozmakla kalmıyor ayrıca küresel değerin yaklaşık yarısını oluşturan ticaret, emtia fiyatları, mali gelirler, döviz 
gelirleri, yabancı finansal akımlar, seyahat kısıtlamaları, turizm, işgücü piyasası gibi küresel değer zincirleriyle birbirine bağlı bir dünya ekonomisini de bozuyor (African Union, 2020: 5-6).

Dünya ekonomisinde dinamik bir görev üstlenen Çin'de üretim-tedarik ve pazarlama zincirinde meydana gelen sarsıntılar tüm dünya ekonomilerini olumsuz etkiledi. Ülkeler arasında lojistik faaliyetlerin durma noktasına gelmesi finansal piyasalarda panik oluşturdu. Birleşmiş Milletler Kalkınma ve Ticaret Konferansı (United Nations Conference on Tradeand Development, 2020) raporu göstermektedir ki; dünya imalat sanayi üretiminde kullanılan ara malların yaklaşık \%7'si Çin'den ithalat edilmektedir. Sadece üretimde değil küresel tüketimde de büyük bir yere sahip olan Çin'in günümüzde dünya GSYH 'sının yaklaşık \%16'sını oluşturmaktadır. Dünya ticaretinin en uğrak 10 limanının 7'si bu ülkede bulunmaktadır (Voyvoda ve Yeldan, 2020: 3). Başlangıç olarak Çin'de başlayan üretim azalması, önce Asya ülkelerine sırasıyla Avrupa, Amerika ve tüm dünyada tedarik zincirinin bozulmasına neden olmuştur. Avrupa ülkeleri içerisinde en yaşlı nüfusa sahip ikinci ülke olan İtalya'nın vaka ve ölüm sayısının üstel olarak artması, İngiltere'de pandeminin hızlı artış göstermesi aynı zamanda bu ülkelerde pandemi karşısında tedbir alma konusunda yavaş davranmaları Avrupa'da paniklerin yaşanmasına, ekonomik göstergelerin de hızla düşmesine neden olmuştur. Başta havacılık, turizm ve sanayi sektörleri olmak üzere, büyük ya da küçük ölçekli tüm işletmelerde üretim kaybı yaşanmış, firma gelirlerindeki azalışlar iflaslara ve istihdam kayıplarına neden olmuştur (International Labour Organization, 2020: 2).

2019 yılında, ABD-Çin ticaret savaşları, ABD başkanlık seçimleri ve Brexit ile ilgili bazı endişeler mevcuttu. Bundan ötürü, IMF yüzde \%3.4 civarında 1lımlı bir küresel büyüme öngörmüştür. 2019 verilerine göre yaklaş1k 1,69 trilyon dolar ihracat ve 2,78 trilyon dolar ithalat yapan ABD dünya ticaretinde lokomotif rolünü devam ettirmiştir (Türkiye İhracatçılar Meclisi, 2020:1-28). Ancak Covid-19 salgını beklentilerin değiştirilmesine neden oldu. Covid-19'un etkisiyle firmaların kârlarının daha düşük olacağı gerçeği ortaya çıkmış ve küresel borsalar 24-28 Şubat tarihleri arasında bir haftada yaklaşık 6 trilyon dolarlık kayıp yaşamıştır. Başta havacılık, turizm ve sanayi sektörleri olmak üzere, büyük ya da küçük ölçekli tüm işletmelerde üretim kaybı yaşanmış, işletme gelirlerindeki azalışlar iflaslara ve istihdam kayıplarına neden olmuştur (International Labour Organization, 2020: 2). Her ne kadar bir sonraki hafta iyileşme kaydedilmiş olsa da, S\&P 500 endeksi ABD'de aynı haftada 5 trilyon doların üzerinde değer kaybederken, S\&P 500'ün en büyük 10 şirketi 1,4 trilyon doların üzerinde bir kayıp yaşadı (Ozili ve Arun, 2020:3).

Avrupa Birliği, ABD ve Japonya dünya GSYH'nin yarısını, Çin \%16'sını oluşturmaktadır. $\mathrm{Bu}$ ekonomiler, ticaret, hizmetler sektörü ve imalat sanayi bakımından öndedirler. Salgının etkilerini azaltmaya yönelik alınan önlemler bu ülkelerin sınırlarını kapatmaya ve ekonomik faaliyetlerini önemli ölçüde azaltmaya zorladı ve bu durum ekonomilerin bazılarında durgunluğa yol açmıştır. Bu bağlamda OECD'nin 2020 ekonomik büyüme tahminleri de düşüşler öngörmektedir. (African Union, 2020: 6).

Pandemi, gelişmekte olan ülkelerin ekonomik dengelerini değiştirmiştir. Bu ülkelerde likidite sıkıntısı ve kur baskısı finansal piyasalarda dengenin bozulmasına neden olmuştur. Yoğun sermaye girişinin yaşandığ gelişmekte olan ülkelerde yabancı sermaye girişi tamamen durmuş hatta sermaye çıkışları hız kazanmıştır. İhracat ciddi şekilde azalırken, hammadde ve petrol fiyatlarında yaşanan düşüşler ve dalgalanmalar dış ticareti derinden sarsmıştır. Bu olumsuzluklar gelişmekte olan ülkelerde hisse senetlerinin değer kaybetmesine, borsalardan hızlı bir çıkışa, tahvil ve bona satışlarına neden olmuştur. Aynı zamanda gelişmekte olan ülkelerde yaşanan dolarizasyon etkisi bu ülkelerin yerel para birimlerinin dolar karşısında değer kaybetmesine neden olmuştur. Bu ülkeler arasında başta Meksika, Rusya, Brezilya, Afrika ve Türkiye'yi sıralamak mümkündür. Yaşanan panik dünya ülkelerinin kriz dönemlerinde güvenli liman olarak gördüğü altına ve $\mathrm{ABD}$ tahvillerine yönelmesine yol açmıştır (Yorulmaz ve Kaptan, 2020: 24). 
HSBC, Global Research'ın dünya ekonomilerinde görülen kötü gidişatın 2020 yılsonuna kadar devam etmesi durumunda enflasyon ve büyümeye ilişkin beklentisine Tablo 1'de yer verilmiştir (HSBC, 2020). Aynı tablonun sağ tarafında ise IMF tarafından belirlenen büyüme tahminleri yer almaktadır.

Tablo 1: Dünya ve Bazı Belirgin Ülkeler İçin Enflasyon ve Büyüme Tahminleri

\begin{tabular}{|c|c|c|c|c|c|c|c|c|c|}
\hline & \multicolumn{6}{|c|}{ HSBC Global Research Enflasyon ve Büyüme Tahminleri } & \multicolumn{3}{|c|}{ IMF Tahmini } \\
\hline & \multirow{2}{*}{\begin{tabular}{|c|} 
GSM \\
$\mathbf{H}$ \\
$\%$
\end{tabular}} & \multirow[b]{2}{*}{$\begin{array}{c}\text { Enflasyon } \\
\%\end{array}$} & \multicolumn{2}{|c|}{2020} & \multicolumn{2}{|c|}{2021} & \multirow{2}{*}{$\begin{array}{l}2019 \\
\text { GSM } \\
\text { H \% }\end{array}$} & \multirow{2}{*}{$\begin{array}{l}2020 \\
\text { GSM } \\
\text { H \% }\end{array}$} & \multirow{2}{*}{$\begin{array}{l}2021 \\
\text { GSM } \\
\text { H \% }\end{array}$} \\
\hline & & & $\begin{array}{c}\text { GSM } \\
\mathbf{H} \\
\% \\
\end{array}$ & $\begin{array}{c}\text { Enflasyon } \\
\%\end{array}$ & $\begin{array}{c}\text { GSM } \\
\mathbf{H} \\
\% \\
\end{array}$ & $\begin{array}{c}\text { Enflasyon } \\
\%\end{array}$ & & & \\
\hline Dünya & 2,6 & 3,1 & $-3,3$ & 5,4 & 5,4 & 2,6 & 2,9 & $-3,0$ & 5,8 \\
\hline $\begin{array}{c}\text { Gelişmiş } \\
\text { Ekonomiler }\end{array}$ & 1,7 & 1,5 & $-5,9$ & 5,5 & 5,5 & 1,3 & 1,7 & $-6,1$ & 4,5 \\
\hline $\begin{array}{l}\text { Gelişmekte } \\
\text { Olan } \\
\text { Ekonomiler }\end{array}$ & 4,0 & 4,3 & 0,5 & 5,2 & 5,2 & 3,3 & 3,7 & $-1,0$ & 6,6 \\
\hline ABD & 2,3 & 1,8 & $-6,5$ & 6,0 & 6,0 & 1,6 & 2,3 & $-5,9$ & 4,7 \\
\hline Çin & 6,1 & 2,9 & 3,0 & 6,5 & 6,5 & 1,7 & 6,1 & 1,2 & 9,2 \\
\hline Japonya & 0,7 & 0,5 & $-4,1$ & 2,8 & 2,8 & 0,0 & 0,7 & $-5,2$ & 3,0 \\
\hline Hindistan & 5,3 & 4,8 & 0,0 & 8,1 & 8,1 & 3,9 & 4,2 & 1,9 & 7,4 \\
\hline $\mathbf{A B}$ & 1,2 & 1,2 & $-6,4$ & 6,1 & 6,1 & 1,3 & 1,2 & $-1,8$ & 2,1 \\
\hline İngiltere & 1,6 & 1,8 & $-5,5$ & 6,3 & 6,3 & 1,5 & 1,4 & $-6,5$ & 4,0 \\
\hline Rusya & 1,3 & 4,5 & $-1,5$ & 1,2 & 1,2 & 4,1 & 1,3 & $-5,5$ & 3,5 \\
\hline Brezilya & 1,1 & 3,7 & $-2,7$ & 2,6 & 2,6 & 3,8 & 1,1 & $-5,3$ & 3,5 \\
\hline Türkiye & 0,9 & 15,5 & $-3,2$ & 12,6 & 3,7 & 12,1 & 0,9 & $-5,0$ & 5,0 \\
\hline
\end{tabular}

Kaynak: HSBC, Global Research 2020; International Monetary Fund, 2020:15.

Salgın nedeniyle karantinalar, seyahat kısıtlamaları ve şehirlere giriş-çıkışların kapatılmasını içeren önlemler, toplam talebi azaltmış bu durum ise; turizmi, perakendeciliği, ağırlama endüstrisini ve sivil havacılık gibi hizmet sektörlerini etkilemiştir. Uluslararası emtia talebi özellikle petrol için düşmüş ve yaşanan ekonomik ve finansal belirsizlikler istikrasızlığı biraz daha artırmıştır (Economic and Social Commission for Asia and the Pacific, 2020: 2). Bu durum Şekil 1'de anlatılmıştır. 


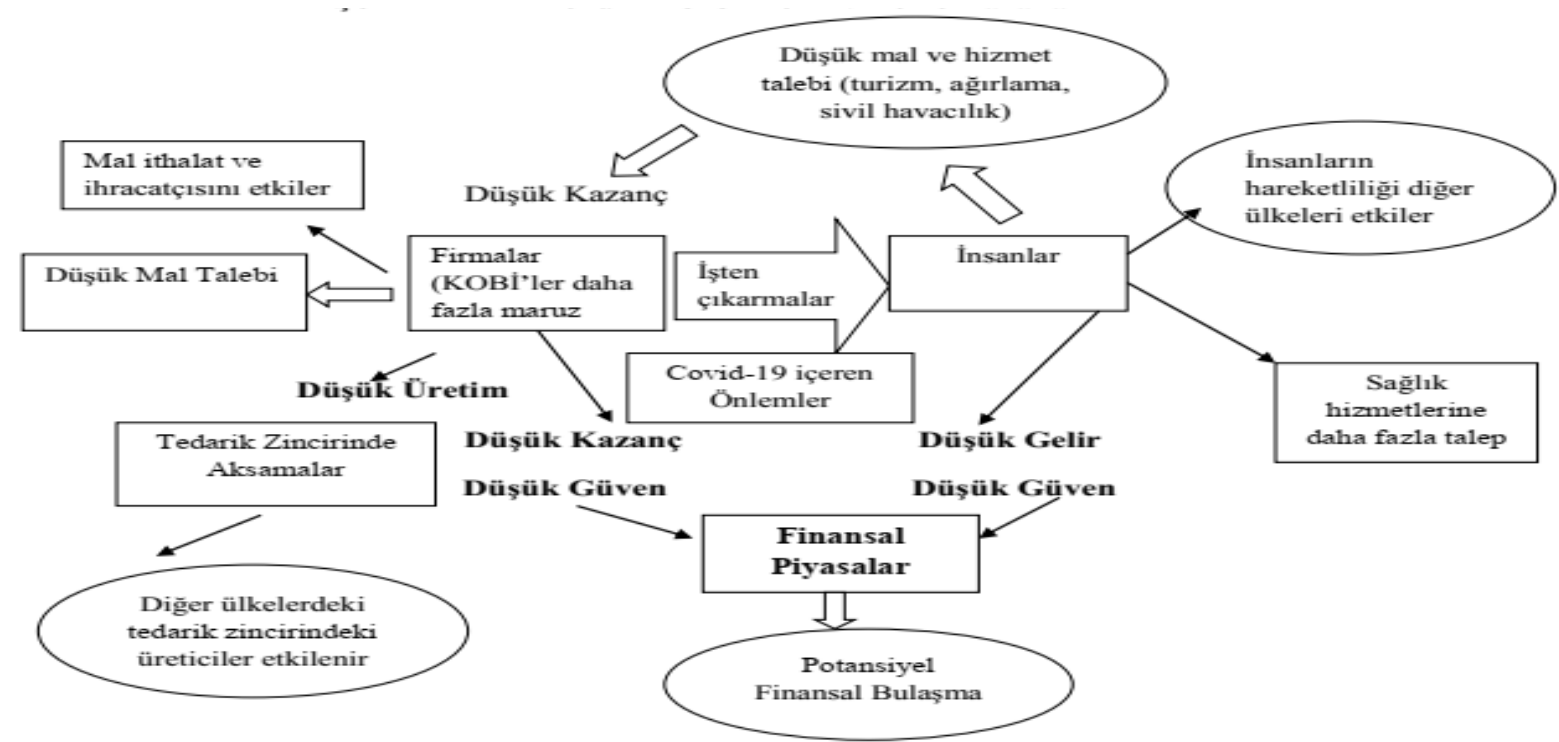

Şekil 1. Covid-19'un Ekonomileri Etkileme Kanalları

Kaynak: ESCAP, 2020: 2.

\section{Dünya'da Covid-19 Salgınına Karşı Alınan Önlemler}

2020 y1lında küresel bir durgunluğun olma ihtimali yüksektir. Bunlardan ilki, dünya ekonomisinin büyüme motorları olan, Çin, $\mathrm{ABD}$ ve Avrupa'nın derinden etkilenmesi. Goldman Sachs, Çin'in 2020'nın birinci çeyreğinde GSYH büyümesinin \% -9'luk bir daralma olacağını tahmin ediyor ve ABD'nin 2008'nin dördüncü çeyreğinde kaydedilen \%-2,2 büyümeden daha kötü olarak 2020'nin ikinci çeyreğinde GSYH büyümesinde \%-6’lık bir düşüşün olacağını öngörmektedir. İkincisi, bulaşıcı etkiler yoluyla, bu büyük ekonomiler dünyanın geri kalanını etkileyecektir. Bu durum Şubat 2020'nin ortalarından bu yana düşen emtia fiyatlarından net bir şekilde görülebilir. Petrol fiyatlarının son 18 yılın en düşük seviyesine indiği görülmektedir. Üçüncüsü, ülkelerin tamamında olmasa bile çoğunluğunu dünyadaki küresel salgından etkilenecektir. Bu durum ise, sağlık hizmetleri, belirsizlikle ilgili doğrudan maliyetleri ifade etmektedir. Ayrıca dolaylı olarak da, işgücü, üretim kapasitesi ve verimlilik gibi hafifletici önlemler ve sınırlamalarla ilgili maliyetleri de ifade etmektedir (Loayza ve Pennings, 2020: 2).

Dahası, salgın iyi yönetilmezse, finansal krizler de dâhil olmak üzere, (iflaslar yaygınlaşırsa, bankalar likit olamaz veya iflas ederse), sektörel çöküşler (örneğin, havayolları, turizm ve konaklama hizmetleri) ve makroekonomik krizler ile refahın ve yoksulluğun azaltılması gibi bir dizi başka krizler ortaya çıkabilir. Covid-19 farklı bir şok haline dönüştüren hususlar nelerdir diye bakıldığında, birincisi oldukça büyük ve bulaşıcı bir küresel şok olmasıdır. İkincisi, aynı anda hem negatif bir arz şoku ve talep şoku olmasıdır. Bir yandan insanların çalışma yeteneğini ve firmalarının üretim kabiliyetlerini azaltırken diğer yandan insanların tüketim eğilimini ve firmaların yatırım yapma durumlarını azaltmaktadır. Üçüncüsü düşük ve orta gelirli ülkelere orantısız bir şekilde zarar verebilir çünkü bu ülkeler doğal şoklara karşı başa çıkacak kaynak ve kapasiteden yoksun olma durumu ile karşı karşıyadırlar (Loayza ve Pennings, 2020: 2).

Hastalığın yayılmasını kontrol altına almak ve etkilerini hafifletmek için yeterli halk sağlığı önlemleri alınmazsa, insan hayatındaki acı ve kayıplar felakette yol açabilir. Buna bağlı olarak, gelir kayıpları da büyük olabilir. Ayrıca ekonomik aktiviteyi yavaşlatarak kontrol altına alma ve azaltma önlemleri pandemiyle ilişkili gelir kayıplarını daha da kötüleştirebilir. Ekonomi için Covid-19 kadar şiddetli bir şok durgunluk anlamına geliyor. Yüksek ölüm oranları ve hastalık oranları işgücü, üretim kapasitesi ve üretkenlikte azalmaya neden olur (arz şoku). Belirsizlikteki artış ve servetteki düşüş 
tüketim ve yatırımda düşüşe neden olur (talep şoku).Küresel bir kriz altında durum daha da kötüleşiyor çünkü olumsuz arz ve talep şokları ticaret, finans ve göç bağlantıları yoluyla tüm ülkelere aktarllyyor (Loayza ve Pennings, 2020: 2-3).

Gelişmekte olan ülkelerde, pandemiye karşı savunmasızlık daha yüksektir ve politika yoluyla başa çıkma yeteneği gelişmiş ülkelerdekinden daha düşüktür. Doğrudan etkilere ilave olarak, küresel şartlara maruz kalan gelişmekte olan ülkeler için Covid-19 keskin bir diş talep şoku da getirmektedir. Bu durum, örneğin ticaret ve turizmin ekonominin büyük bir parçası olan Doğu Asya ülkelerinde, kamu gelirlerinde mal ihracatı ağırlıkta olan ve gelişmiş ülkelerden gelen işçi dövizine önemli ölçüde bağımlı olan gelişmekte olan ülkeler için son derecede önemlidir (Loayza ve Pennings, 2020: 3).

Gelişmekte olan ülkeler aşağıdaki yapısal koşullar nedeniyle daha fazla etkilenebilir (Loayza ve Pennings, 2020: 3-4):

- Halk Sağlığı: Gelişmekte olan ülkelerde sağlık bakım sistemlerinin kapasitesi düşüktür, birçok insanın temel sağlık hizmetlerine erişim yoktur ve sağlık sigortası kapsamında değildir. Bu nedenle sağlı harcamaları riski ve ortalama nüfusun mevcut ve ideal sağlık durumu arasındaki fark büyüktür. Özellikle Covid-19 hastalarını tedavi etme kapasitesi düşük ve hatta orta gelirli birçok ülkede büyük ölçüde yetersizdir.

- İşgücü Piyasaları: Kayıtdışı kavramı gelişmekte olan ülkelerde daha yaygındır. Düşük ve orta gelirli ülkelerde toplam istihdamın yüzde 50 ila yüzde 90'1 kayıt dışı istihdamdan oluşmaktadır. Kayıt dışı çalışanlar işsizlik sigortası, sağlik sigortası ve ücretli izin gibi faydalardan mahrumdurlar. Bu kişiler Covid-19'un sağlık üzerindeki etkileri yanı sıra aynı zamanda hastalığın yayılmasını azaltmak için uygulanan sınırlama ve hafifletme önlemlerinden de etkilenmektedirler. Çoğu kayıt dışı iş̧̧i, özellikle de kendi işinde çalışanlar temel günlük ihtiyaçlarını karşılamaları günlük çalışmalarına bağlıdır. Uzun süre çalışmazlarsa eğer ailelerinin geçimleri de riske girmektedir.

- Mali Alan: Düşük ve orta gelirli ülkelerin yeterli mali alanı yoktur başka bir ifadeyle büyük bir olumsuz şok karşısında kamu kaynaklarını ve fonlarını kullanma yeteneği yetersizdir. Gelişmekte olan ülkeler, gelişmiş ülkelere göre daha yüksek kamu borç/GSYH oranına sahip olmamasına rağmen, onların borçları döviz kuru ve vade riskine daha fazla maruz kalır, kredi notları düşüktür ve finansal piyasaları daha sığdır. Ayrıca, küçük bir vergi tabanı ve daha az verimli vergi idaresi nedeniyle konjonktürel maliye politikasının uygulanması gelişmekte olan ülkelerde gelişmiş ülkelere göre daha zordur.

- Yönetim: Yönetim kalitesi, bir ülkenin şokları yönetme ve yardım sağlama kapasitesinin etkinliğini belirler. Gelişmekte olan ülkelerin çoğu, yolsuzluk, şeffaflık ve hesap verilebilirlik eksikliği, düşük bürokratik yetkinlik ve ağır düzenleyici sistemlere maruz kalmaktadır. Covid-19'un zorluğu ile karşı karşıya kalan gelişmekte olan ülke yönetimleri krizle başa çıkmak için karmaşık önlemler almayı zor bulabilirler.

Dünya'da ekonomi yönetimleri korona virüsün etkilerini sınırlandırmak amacıyla ve salgınla mücadele için çözüm yöntemleri geliştirmişlerdir. Bu bağlamda ABD Merkez Bankası Mart ay1 içerisinde faiz indirimine gitmiş, politika faizini \%0-0.25 aralığına çekmiştir. Aralarında Türkiye'nin bulunduğu Merkez bankaları da aynı uygulamaları sürdürmüştür. Merkez Bankalarının aldığı tedbirlere ilaveten ekonomiyi devreye sokmak amacıyla hükümetler teşvik paketleri açılamaya başlamışlardır. Bireysel harcamaları ve talebi artıracak teşvik paketi için ihtiyaç duyulan nakit desteğinin sağlanması amacıyla gerekli tedbirler alınmıştır. Evlerde kalan tüketicinin sabit giderlerini karşılamak ve harcama yapmalarının önünü açacak kredi teşvikleri paketlerine yer verilmiştir. Diğer yandan temerrüt riski artan şirketlere maaş yardımı, vergi indirimi, kredi limitlerinin artırılması ve 
borçların ötelenmesi gibi çeşitli teşvikler sağlanırken, turizm ve havacılık sektörüne yönelik destekler ön plana çıkmıştır.

Korona virüs nedeniyle ortaya çıkan kriz sadece arzı (mal ve hizmet üretimini) değil aynı zamanda talebi de (tüketim ve yatırım) etkileyerek ekonomik şoka neden olmuştur. Başlangıçta Asya'daki üretiminde aksamalar şimdilerde dünya çapında tedarik zincirine yayılmıştır. Hangi büyüklükte olursa olsun işletmelerin tamamı, özellikle havacılık, turizm ve konaklama endüstrilerinde ciddi zorluklar yaşanmakta ve belirli sektörlerde gelir, iflaslar ve iş kayıpları söz konusudur. KOBI'ler için ticari faaliyetleri sürdürmek zor hale gelmiștir. Seyahat yasakları, sınır kapanışları ve karantina önlemlerine takiben, çok sayıda kişi işlerine gidemez olmuş bu durum özellikle kayıt dışı ve serbest çalışanların gelirleri üzerinde olumsuz etkileri de beraberinde getirmiştir (International Labour Organization, 2020: 2).

Ülkeler korona virüsle ilgili tedbirler almaya başlamışlardır. Covid-19 salgının ilk aşamasında, bazı ülkeler hastalığın yayılmasıyla mücadele etmek ve gerek ekonomi gerekse işgücü piyasası üzerindeki etkilerini azaltmak için bazı tedbirler alınmıştır. Bunlar; işyerinde çalışanların korunması, ekonomi ve işgücü talebini teşvik etmek, istihdamı ve geliri desteklemek olarak siralamak mümkündür (International Labour Organization, 2020: 9).

Covid-19 salgını önemli ölçüde acil sağlık durumu ve ciddi bir ekonomik krizi tetiklemiştir. Temel kısıtlama önlemleri ve gönüllü uzaklaştırma çabaları nedeniyle milyonlarca kişi işini kaybetmiştir. Ağırlaşan küresel ekonomik koşullar, yeterli sağlık donanımına sahip olmayan gelişmekte olan ekonomilerin zorluklarla karşı karşıya kalmasına neden olmaktadır. Bu bağlamda, politika yapıcılar, hastalığın yayılmasını engellemek ve ekonomik hasarı sınırlandırmak amacıyla bazı adımlar attılar. Birçok ülkede salgından en fazla etkilenen ve korumasız kişilere karşı maliye politikaları etkin bir şekilde uygulanmaya başladı. En önemli mali işlemler salgının daha fazla kaydedildiği gelişmiş ülkelerde uygulanmıştır. Bazı istisnalar dışında, enfeksiyon oranlarındaki nispeten gecikmeli artış, sınırlı politika alanı ve yüksek borç konusundaki endişeler nedeniyle, gelişmekte olan piyasalar ve gelişmekte olan ekonomiler bugüne kadar daha küçük mali önlem paketlerini kullanmışlardır. Para politikasının gevşetilmesi ve finans sektörüne yönelik uygulanan politikalar, finansal koşulların dengelenmesine yardımcı olmuştur (International Monetary Fund, 2020: 1).

Küresel salgınla beraber gelişmekte olan bazı pazarlar ve bazı ekonomiler ciddi zorluklarla karşı karşıya kalmıştır. Benzeri görülmemiş küresel ekonomiyi vuran şokların çokluğu, gelişmekte olan piyasalar ve gelişmekte olan ekonomiler zayıf sağlık sistemleri göz önüne alındığında, daha kısıtlı makroekonomik politika alanı, genellikle daha az çeşitlendirilmiş ekonomiler ve bazı durumlarda yüksek borç sıkıntısı riski gibi ilave zorluklarla karşı karşıya kalmışlardır. Politika yapıcılar çok sayıda ülkede önlemler almışlardır. Bu bağlamda, politika yapıcılar virüsün yayılmasını kontrol altına almaya ve sağlık sisteminin kaynaklarını desteklemeye çalışmışlardır. Politika yapıcılar kamu harcama kalemlerini öne çekmek, yeni tesisler talep etmek, personel ve gönüllüleri işe almak, tıbbi malzeme almak ve araştırmaları finanse etmek de dâhil olmak üzere sağlık sistemine kaynak sağlamak için çalışmalar başlatmışlardır (International MonetaryFund, 2020: 6-7).

Şekil 2'de Dünya ülkeleri tarafından pandemi önleme politikaları ve uygulanan ekonomi politikaları gösterilmiştir. 


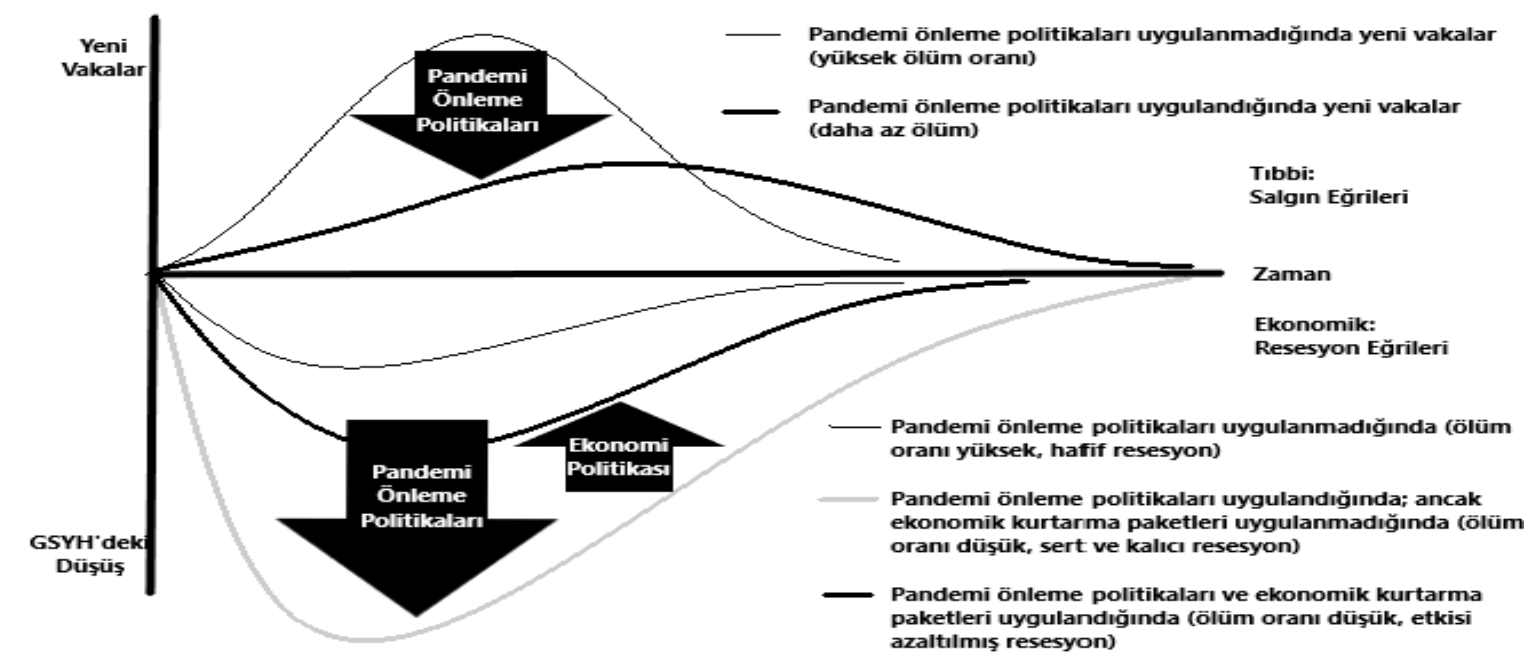

Şekil 2. Pandemi Önleme Politikaları ile Uygulanan Ekonomi Politikaları

Kaynak: Baldwin, 2020.

Şekil 2'de görüldüğü üzere tıbbi pandemi önlem politikaları uygulandığında ölüm oranının düştügü belirlenmiştir. Ayrıca tıbbi pandemi önlem politikalarına ek olarak ekonomik kurtarma politikalarının eklenmesi krizin hafif resesyona dönüşmesine neden olmuştur.

\subsection{Covid-19 Salgını Sürecinde Ülkeler Tarafından Alınan Hızı Politika Tedbirleri}

Kumar (2020), Covid-19'un küresel ekonomiyi etkileme sürecini; üretim üzerindeki doğrudan etki, tedarik zinciri ve piyasaların bozulması, şirketler ve finansal piyasalar üzerindeki finansal etki olarak üçe ayırmıştır (Mishra, 2020: 6-7). Dünyada politika yapıcılar tarafından korona virüs kaynaklı küresel durgunlukla başa çıkmak için uygulanan politika önemlerini dört kategoride toplamak mümkündür. Bunlar; parasal tedbirler, mali tedbirler, halk sağlığına ilişkin önlemler ve insanın kontrolüne dayalı önlemlerdir (Ozili ve Arun, 2020: 16).

Tablo 2: 2020 Küresel Durgunluğa Karşı Dünya Ülkeleri Tarafından Alınan Hızlı Politika Tedbirleri

\begin{tabular}{|c|c|c|}
\hline Tür & $\begin{array}{c}\text { Politika Yapıcılar Tarafından Alınan Hızlı } \\
\text { Politika Önlemleri }\end{array}$ & Ülkeler \\
\hline \multirow{6}{*}{$\begin{array}{l}\text { Para Politikası } \\
\text { Önlemleri }\end{array}$} & $\begin{array}{l}\text { (i) Bankalara zorlayıcı düzenlemeler, (ii) Covid- } \\
19 \text { etkilenen borçlulara anapara ve faiz } \\
\text { moratoryumu }\end{array}$ & İ́landa, Çin, Nijerya ve İtalya \\
\hline & $\begin{array}{l}\text { Merkez bankalarının finansal (tahvil ve hisse } \\
\text { senedi) piyasalara likidite sağlanması }\end{array}$ & Çin, ABD \\
\hline & $\begin{array}{l}\text { Merkez bankalarının hızla değer kazanan tahvil } \\
\text { ve menkul kıymetleri satın alması }\end{array}$ & Avustralya, AB ve Kanada \\
\hline & $\begin{array}{l}\text { Merkez bankaları tarafından faiz oranlarının } \\
\text { düşürülmesi }\end{array}$ & $\begin{array}{l}\text { Türkiye, ABD, Yeni Zelanda, } \\
\text { Japonya ve İngiltere, } \\
\text { Nijerya, Güney Kore ve Kanada }\end{array}$ \\
\hline & $\begin{array}{l}\text { Bankalara, KOBİlere, halk sağlığı sektörüne, } \\
\text { bireylere ve önemli işletmelere sürekli kredi } \\
\text { akışı }\end{array}$ & $\begin{array}{l}\text { Avustralya, Nijerya, ABD ve } \\
\text { İngiltere }\end{array}$ \\
\hline & $\begin{array}{l}\text { Covid-19 salgından en fazla etkilenen sektörler } \\
\text { ve endüstriler için büyük bir teşvik paketini } \\
\text { onaylayan hükümetler }\end{array}$ & $\begin{array}{l}\text { İngiltere, ABD, Avustralya ve } \\
\text { Nijerya }\end{array}$ \\
\hline
\end{tabular}




\begin{tabular}{|c|c|c|}
\hline \multirow[t]{2}{*}{ Mali Önlemler } & Bireyler için gelir desteği sağlanması & $\begin{array}{l}\text { Avustralya, ABD, İngiltere ve } \\
\text { Hindistan }\end{array}$ \\
\hline & $\begin{array}{l}\text { Her hane halkını desteklemek için sosyal yardım } \\
\text { ödemeleri }\end{array}$ & Avustralya, ABD \\
\hline \multirow{4}{*}{$\begin{array}{l}\text { Halk Sağlı̆̆ı } \\
\text { Önlemleri }\end{array}$} & Halk Karantinası & $\begin{array}{l}\text { Hindistan, ABD, İngiltere ve } \\
\text { neredeyse her ülke }\end{array}$ \\
\hline & Sinır Karantinası & $\begin{array}{l}\text { Polonya, Vietnam, Hindistan, } \\
\text { İngiltere, ABD, Pakistan, } \\
\text { Avustralya ve Kolombiya }\end{array}$ \\
\hline & Evde kalma politikası & İtalya, İran, Nijerya ve İngiltere \\
\hline & Sosyal mesafe politikası & $\begin{array}{l}\text { Güney Afrika, ABD, İngiltere, } \\
\text { BAE, Singapur, } \\
\text { Nijerya, Japonya, Çin, Hindistan, } \\
\text { Almanya, } \\
\text { Pakistan, Avustralya, Güney Kore } \\
\text { ve İsrail }\end{array}$ \\
\hline \multirow{6}{*}{$\begin{array}{l}\text { İnsanları } \\
\text { Kontrol } \\
\text { Önlemleri }\end{array}$} & $\begin{array}{l}\text { Aşırı kalabalık cezaevlerinden mahkûmların } \\
\text { geçici olarak serbest bırakılması }\end{array}$ & İran, ABD \\
\hline & Hava, kara ve deniz sınırlarının kapatılması & $\begin{array}{l}\text { Tayvan, Hindistan, Meksika, } \\
\text { ABD, Almanya, } \\
\text { Sirbistan ve Nijerya }\end{array}$ \\
\hline & Okulların kapatılması & $\begin{array}{l}\text { İngiltere, İspanya, İtalya, Güney } \\
\text { Afrika, Nijerya } \\
\text { Ve ABD }\end{array}$ \\
\hline & $\begin{array}{l}\text { Korona virüse karşı evde kalma karantinasında } \\
\text { kolluk kuvvetlerinin kullanılması }\end{array}$ & $\begin{array}{l}\text { Malezya, İtalya, ABD, İsrail, } \\
\text { Güney Afrika ve İspanya }\end{array}$ \\
\hline & Seyahat Yasağ1 & $\begin{array}{l}\text { AB, ABD, Arjantin, Avusturya, } \\
\text { Avustralya, } \\
\text { Bolivya, Kamboçya, Kanada, Çin, } \\
\text { Pelerin } \\
\text { Verde, Kamboçya, Kolombiya, } \\
\text { Hirvatistan, } \\
\text { Danimarka, Mısır, Almanya, } \\
\text { Yunanistan ve } \\
\text { Haiti }\end{array}$ \\
\hline & Vize reddi ve askiya alma & $\begin{array}{l}\text { Güney Afrika, Kanada, Singapur, } \\
\text { Çin, } \\
\text { Nijerya, Gana, Kenya, Bolivya ve } \\
\text { Brezilya }\end{array}$ \\
\hline
\end{tabular}

Kaynak: Ozili ve Arun, 2020: 15.

\subsection{Covid-19 Sürecinde Ülkeler Tarafından Alınan Maliye Politikası Önlemleri}

Maliye politikaları uygulamaları, bazı ülkelerde oldukça büyük tamamlayıcı otomatik dengeleyiciler olarak kullanılmıştır. Bütçe üzerindeki önlemlerin miktarı önemli ölçüde değiştirilmiş, G-20 ülkeleri GSYH'nin \%1,6'sını nakit olmayan gelir ve harcama önlemleri olarak ilan etmiştir. Yardım paketleri; kredi programları, garantiler, borçların iptali, nakit akışı sıkıntısı çeken firmaların iflastan kaçınmalarına ve işleri sürdürmelerine yardımcı olacak sübvansiyonlar, bireylere yönelik transfer harcamaları, insanların temel ihtiyaçlarını karşılayacak yeterli gelire sahip olmalarını sağlamak için geliştirilmiş işsizlik sigortası ve refah sistemlerini içermektedir. Firmalara ve bireylere vergi muafiyeti, faiz indirimleri, geçici feragatler, ertelemeler, muafiyetler ve hızlandırılmış indirimler aracılığı ile sağlanmıştır. Örneğin ABD'nin mart ayının sonunda onaylanan yardım paketi; hane halklarının \%90'ına nakit ödeme, gıda yardımı, genişletilmiş işsizlik yardımları, sıkıntılı sektörlerdeki firmalara (örneğin havayolları) destek, bordro vergisi ertelemesi ve KOBİ'ler 
için maaş koruması önlemlerini içermektedir. Almanya'nın mali paketi ise; kısa vadeli iş yardımı, genişletilmiş çocuk bakımı yardımları ve kamu kredisi garantilerini içermektedir. Japonya'nın Nisan ayı başında ilan edilen teşvik paketi ise, salgından etkilenen hane halkı ve firmalara transferler, vergi ödemelerinin ertelenmesi, sosyal güvenlik katkıları ve özel finans kuruluşlarından sağlanan imtiyazlı kredileri içermektedir. İngiltere'nin teşvik paketi ise, işten çıkarılan işçilerin ücretlerinin \%80'ini ödemeyi içermektedir. Çin ise, Covid-19 etkilenen Hubei Eyaletine ek sağlık personelini transfer etmenin yanı sıra, ulusal düzeyde sübvansiyonlar ve hedeflenen vergi indirimleri sağlamıştır (International Monetary Fund, 2020: 8-9).

Gelişmiş ülkeler, Covid-19 salgının ekonomik etkilerini karşı büyük sağlık ve kamu harcamaları programları başlatmıştır. Gelir düzeyi düşük olan ülkelerin mali ve parasal tepkiler daha sınırlı kalmış ve uluslararası kuruluşların yardımları konusunda oynayacakları roller için fikirler tartışılmıştır. Çoğu gelişmiş ülke, Covid-19 salgınına büyük ekonomik tepkiler vermiş ve işletmelerin kapanmasına, işsiz sayısının artmasına neden olan etkileri hafifletmek amacıyla harcamaları artırmış ve para politikasını kullanmıştır (Mishra, 2020: 9).

Gelişmekte olan piyasalar ve gelişmekte olan ekonomilerde nispeten sınırlı mali destek sağlanmıştır. Bazı büyük gelişmekte olan piyasa ekonomileri büyük mali destek sağlamış olsa da (Örneğin Brezilya, Çin, Endonezya, Türkiye) bütçe dışı mali destek ortalaması G-20'de gelişmekte olan 10 pazar ekonomisinin GSYH'nin \%1'ini oluştururken, G-20'deki gelişmiş ekonomilerin ortalaması GSYH'nin \%3.7'sini oluşturmaktadır. Bazı düşük gelirli ülkeler hane halklarına ve firmalara mali destek sağlamasına rağmen, mali alanın krize girmesinin çok sınırlı olduğu birçok yerde, para politikası borçlanma maliyetlerini düşürerek ve yaşamsal likidite sağlayarak yardımcı olmuştur (International Monetary Fund, 2020: 9-10) Covid-19'un olumsuz etkilerini azaltmak için birçok ülkede alınan maliye politikası önlemlerine Tablo 3'de yer verilmiştir.

Tablo 3: Koronavirüsün Yayılmasıyla Mücadeleye Yönelik Maliye Politikası Önlemleri

\begin{tabular}{|c|c|c|c|c|c|}
\hline Ülkeler & $\begin{array}{c}\text { Doğrudan } \\
\text { Harcamalardaki } \\
\text { Toplam Artış }\end{array}$ & $\begin{array}{c}\text { GSYH'nin } \\
\text { yüzdesi }\end{array}$ & $\begin{array}{l}\text { Krediler ve } \\
\text { Kredi Yoluyla } \\
\text { Mali Destek ve } \\
\text { Teminatlar }\end{array}$ & $\begin{array}{c}\text { GSYH'nin } \\
\text { yüzdesi }\end{array}$ & Uyarilar \\
\hline$\overline{\mathrm{ABD}}$ & 484 milyar dolar & 2.4 & 2,3 ton USD & 9.3 & $\begin{array}{l}\text { Önlem İlan } \\
\text { Edildi }\end{array}$ \\
\hline $\begin{array}{l}\text { Birleşik } \\
\text { Krallık }\end{array}$ & 350 milyar Sterlin & 11.8 & $\begin{array}{l}330 \text { milyar } \\
\text { sterlin }\end{array}$ & 10.7 & $\begin{array}{c}\text { Önlem İlan } \\
\text { Edildi }\end{array}$ \\
\hline Kanada & 107 milyar dolar & 6.2 & - & - & $\begin{array}{l}\text { Önlem İlan } \\
\text { Edildi }\end{array}$ \\
\hline Çek & $\begin{array}{c}100 \text { milyar Çek } \\
\text { Korunası }\end{array}$ & 1.8 & $\begin{array}{c}900 \text { milyar Çek } \\
\text { Korunas1 }\end{array}$ & 15.9 & $\begin{array}{l}\text { Önlem İlan } \\
\text { Edildi }\end{array}$ \\
\hline Polonya & $\begin{array}{c}212 \text { milyar Polonya } \\
\text { Zlotisi }\end{array}$ & 9 & $\begin{array}{c}\text { 700mn Polonya } \\
\text { Zlotisi }\end{array}$ & 0.1 & - \\
\hline Romanya & 9 milyar Rumen Leyi & 0.9 & $400 \mathrm{mn}$ Euro & 0.2 & - \\
\hline Rusya & 1.4. ton Rus Rublesi & 0.3 & - & - & $\begin{array}{l}\text { Önlem İlan } \\
\text { Edildi }\end{array}$ \\
\hline Misır & 50 milyar Mısır lirası & 0.8 & $\begin{array}{c}50 \text { milyar Misır } \\
\text { lirası }\end{array}$ & 0.8 & - \\
\hline İsrail & $\begin{array}{l}2.8 \text { milyar İsrail } \\
\text { Şekeli }\end{array}$ & 0.4 & - & - & - \\
\hline $\begin{array}{c}\text { Suudi } \\
\text { Arabistan }\end{array}$ & $\begin{array}{l}120 \text { milyar Suudi } \\
\text { Arabistan Riyali }\end{array}$ & 3.9 & - & - & - \\
\hline Türkiye & 100 milyar Lira & 185 & - & - & $\begin{array}{l}\text { Artan kredi, } \\
\text { düşük vergi ve } \\
\text { ertelenmiş } \\
\text { ödemeler }\end{array}$ \\
\hline
\end{tabular}




\begin{tabular}{|c|c|c|c|c|c|}
\hline Nijerya & $\begin{array}{c}3.5 \text { ton Nijerya } \\
\text { Nairası }\end{array}$ & 2.3 & 6.9 milyar dolar & 7.5 & $\begin{array}{c}\text { Önlem İlan } \\
\text { Edildi }\end{array}$ \\
\hline Hindistan & 1.7 lakh rupi & 967 & 1 milyar dolar & 0.04 & $\begin{array}{c}\text { Dünya Bankas1 } \\
\text { kredisi }\end{array}$ \\
\hline
\end{tabular}

Kaynak: Ozili ve Arun, 2020: 17.

\subsection{Covid-19 Sürecinde Ülkeler Tarafından Alınan Para Politikası Önlemleri}

Covid-19 sürecinde merkez Bankaları da hızlı bir şekilde harekete geçmiştir. Bu bağlamda merkez bankaları ilk olarak politika faizlerini düşürerek ve uzun vadeli faiz oranları üzerinde aşağı doğru baskı yapmak için bazı durumlarda varlık satın alma durumlarını genişletilmesini de içeren uygulamalar ile para politikasını önemli ölçüde gevşetmişlerdir (Örneğin. Avustralya, Brezilya, Kanada, Euro bölgesi, Hindistan, Japonya, Kore, Güney Afrika, Türkiye, İngiltere, Amerika Birleşik Devletleri). İkincisi, banka rezerv gereksinimlerini düşürmek, teminat koşullarını kolaylaştırmak ve likidite repo operasyonlarının koşullarını büyütmek ve genişletmek de dâhil olmak üzere bankacılık sistemlerine likidite enjekte etmişlerdir (Örneğin. Avustralya, Brezilya, Kanada, Çin, Euro bölgesi, Hindistan, Japonya, Kore, Rusya, Güney Afrika, Türkiye, İngiltere, Amerika Birleşik Devletleri). Üçüncüsü, birkaç Merkez Bankası küresel ABD doları fonlama piyasasındaki daralmanın iyileşmesini sağlamak amacıyla takas hattı düzenlemelerine katılmayı kabul etmiştir. Kısa vadeli fon piyasalarının likiditesini ve işleyişini artırmak ve daha geniş ekonomiye kredi akışını sürdürmek amaciyla, birkaç merkez bankası; ticari senetler, kurumsal tahviller, hisse senetleri ve varlığa dayalı menkul kıymetler piyasalarını içeren çeşitli pazar segmentlerini destekleyen faaliyetleri genişleten ya da artıran uygulamalara gitmiştir. (Örneğin. Kanada, Euro bölgesi, Japonya, İngiltere, Amerika Birleşik Devletleri). Bunun yanı sıra dövize müdahalelerde bulunulmuştur. Dalgalı döviz kuru uygulayan bazı ekonomiler döviz likiditesini artırmak ve oynaklığı sınırlamak için döviz piyasalarına müdahale etmişlerdir. (Örneğin. Brezilya, Endonezya, Meksika, Rusya, Türkiye). Finansal sektöre yönelik önlemler alınmıştır. Yapılan uygulamalar, finansal istikrarı korurken ekonomiye kredi akışını sağlamayı amaçlamıştır. (Örneğin, bankaları sermaye kullanmaya teşvik etmek ve likidite tamponları, pandemiden etkilenen borçlular için kredinin yeniden yapılandırması, yeniden düzenleme ve sorunlu risklere maruz kalmaları ve kamu kredi garantileri için bankalara geçici esneklik getirilmesi, provizyon şartlarına ilişkin açıklama) (International MonetaryFund, 2020: 9).

Tablo 4: Covid-19'un Orta ve Doğu Avrupa, Orta Doğu ve Afrika ülkelerinde Olumsuz Ekonomik Etkilerini Azaltmaya Yönelik Açılanan Para Politikası Tedbirleri

\begin{tabular}{|c|c|c|c|c|c|c|}
\hline \multirow[t]{2}{*}{ Ülkeler } & \multicolumn{3}{|c|}{ Para politikası oranı } & \multirow[b]{2}{*}{$\begin{array}{c}\text { Yeni } \\
\text { varlık } \\
\text { alımları }\end{array}$} & \multirow[b]{2}{*}{$\begin{array}{l}\text { Kredi ve } \\
\text { Likidite } \\
\text { İmkânı } \\
\end{array}$} & \multirow[b]{2}{*}{$\mathbf{E k}$} \\
\hline & $\begin{array}{c}1 \text { Ocak } \\
\text { itibariyle }\end{array}$ & $\begin{array}{l}\text { Şimdiki } \\
\text { Oran }\end{array}$ & $\begin{array}{l}\text { 2.Çeyrek } \\
\text { Sonu }\end{array}$ & & & \\
\hline Çek & 2.00 & 1.75 & 1.00 & $\begin{array}{l}\text { Devlet } \\
\text { Tahvili }\end{array}$ & $\begin{array}{c}\text { Artırılmış } \\
\text { Forex } \\
\text { Takas } \\
\text { Stoku }\end{array}$ & - \\
\hline Macaristan & 0.90 & 0.90 & 0.90 & - & - & \\
\hline Polonya & 1.50 & 1.00 & 0.50 & $\begin{array}{l}\text { Devlet } \\
\text { Tahvili }\end{array}$ & - & $\begin{array}{l}\text { Azalan rezerv } \\
\text { gereksinimi ve } \\
\text { artan faiz oranı }\end{array}$ \\
\hline Romanya & 2.50 & 2.00 & 1.50 & $\begin{array}{l}\text { Devlet } \\
\text { Tahvili }\end{array}$ & & \\
\hline
\end{tabular}




\begin{tabular}{|c|c|c|c|c|c|c|}
\hline Rusya & 6.25 & 6.00 & 6.00 & $\begin{array}{c}\text { Forex } \\
\text { Sat1ş }\end{array}$ & - & - \\
\hline Ukrayna & 13.50 & 10.00 & 8.50 & $\begin{array}{c}\text { Forex } \\
\text { Sat1ş }\end{array}$ & - & - \\
\hline Misir & 12.25 & 9.25 & 9.25 & - & - & $\begin{array}{c}\text { Şirketler ve hane halkları } \\
\text { üzerindeki kredi yükünü } \\
\text { azaltmak için alınan } \\
\text { tedbirler }\end{array}$ \\
\hline İsrail & 0.25 & 0.25 & 0.10 & $\begin{array}{l}\text { Devlet } \\
\text { Tahvili }\end{array}$ & - & - \\
\hline $\begin{array}{c}\text { Suudi } \\
\text { Arabistan }\end{array}$ & 2.25 & 1.00 & - & - & - & - \\
\hline Türkiye & 12.00 & 9.75 & - & - & - & $\begin{array}{c}\text { Yeni kredi imkânları, } \\
\text { azaltılmış rezerv } \\
\text { gereksinimleri gibi } \\
\text { önlemler }\end{array}$ \\
\hline Gana & 16.00 & 14.50 & 14.50 & - & - & $\begin{array}{l}\text { Birincil rezerv koşulunun } \\
\text { azaltılması, likiditeyi } \\
\text { serbest bırakmak için } \\
\text { oranlar }\end{array}$ \\
\hline Kenya & 8.50 & 7.25 & - & & & $\begin{array}{l}\text { Azalan nakit rezervi } \\
\text { oranı, geniş kredi } \\
\text { yeniden yapılandırma }\end{array}$ \\
\hline Nijerya & 13.50 & 13.50 & - & & & $\begin{array}{l}\text { Çoklu Forex rejimleri, } \\
\text { düşük müdahale oranı, } \\
\text { federal faiz oranının } \\
\text { düşürülmesine yönelik } \\
\text { önlemler }\end{array}$ \\
\hline Hindistan & 5.15 & 4.4 & - & - & $\begin{array}{l}3.4 \text { lakh } \\
\text { rupi likidite } \\
\text { enjektesi }\end{array}$ & $\begin{array}{l}\text { Maliyet gelir oranı \%3’e } \\
\text { düşürüldü. Vadesiz } \\
\text { krediler için üç aylık } \\
\text { moratoryum. GSYH } \\
\text { \%3.4'ü toplam likidite } \\
\text { enjekte edildi. }\end{array}$ \\
\hline $\begin{array}{l}\text { Güney } \\
\text { Afrika }\end{array}$ & 6.50 & 5.25 & 4.75 & - & - & - \\
\hline
\end{tabular}

Kaynak: Ozili ve Arun, 2020: 18.

\section{Türkiye'de Covid-19 Sürecinde Uygulanan Politikalar}

Pandemi sürecine tüm dünya ülkeleri gibi Türkiye'de hazırlıksız yakalanmıştır. Türkiye ekonomisini rahatlatmak adına alınan tedbirler hızla devreye sokularak ekonomiye can suyu aktarılmaya çalışılmıştır. Diğer dünya ülkelerinde olduğu gibi Türkiye'de önce tıp sağlığı alanında tedbirlere öncelik vermiş̧ir. Covid-19 salgını hem sağlık hem de sosyal ve ekonomik anlamda mücadele gerektiren çok boyutlu bir süreci kapsamaktadır. İnsan sağlığının devamını sağlamak ancak virüsün yayılmasını önlemekle mümkün olacaktır. Bu bağlamda sosyal hayatta insanlar arasında mesafenin korunması ve sosyal izolasyon şu an için en etkili tedbir yöntemi olarak uygulanmaktadır.

Türkiye pandemi ile mücadelede önceliğini sağlık tedbirlerine vermiştir. Covid-19 hastalığının bulaşıcılık özelliğine sahip olmasından dolayı seyahat kısıtlaması yasağı getirilmiş, havalimanlarında gerekli önlemler alınarak 22 Ocak 2020'de Wuhan'dan İstanbul'a, 5 Şubat 2020 
tarihinden sonra da Çin'den Türkiye'ye tüm uçuşlar iptal edilmiştir. 23 Şubat'ta Türkiye- İran sinır kapıları kapatılmış ardından Mart ayının son haftası itibariyle tüm dünya ülkelerine uçuşlar geçici olarak durdurulmuştur. Acil eylem planı olarak referans hastaneler belirlenmiş, yerli tanı kitleri uygulamaya sokulmuştur. Yoğun bakım üniteleri 100 bin ferde hizmet verebilecek şekilde kapasite artışına gidilmiştir. Hastalığın ilerlemesiyle İstanbul'da iki büyük hastane faaliyete geçirilmiştir. Bu hastanelerin pandemiden sonra da uluslararası alanda potansiyeli olan Türkiye'nin sağlık turizmi konusunda faaliyet göstermesi hedeflenmiştir. Virüsün yayılmaya başlamasına firsat vermeden 15 Mart'tan itibaren ilköğretim, lise ve üniversitelerde eğitime ara verilmiştir. İlk öğretim ve liselerde "EBA TV" ismiyle bir kanal oluşturularak online eğitim verilmeye başlanmıştır. Benzer şekilde üniversiteler kendi alt yapılarını oluşturarak uzaktan eğitim sistemi ile lisans, yüksek lisans ve doktora eğitimlerini devam ettirmişlerdir (Duran, 2020: 20-21).

Ekonomik anlamda para politikaları ile pandemi sürecinin olumsuz etkileri azaltılmaya başlanmış daha sonra maliye politikası ile devam edilmiştir. Nisan ayında doğrudan gelir aktarım mekanizmaları ile devam edilen süreç Mayıs ayında kredilerde yapılan faiz indirimi ile sürdürülmüştür. Türkiye' de hizmet sektöründe çalışanlar bu süreçte en fazla olumsuz etkilenenler olmuştur. Türkiye'de Covid-19 sürecinde alınan tedbirler genel hatlarıyla Şekil 3'de sıralanmıştır.

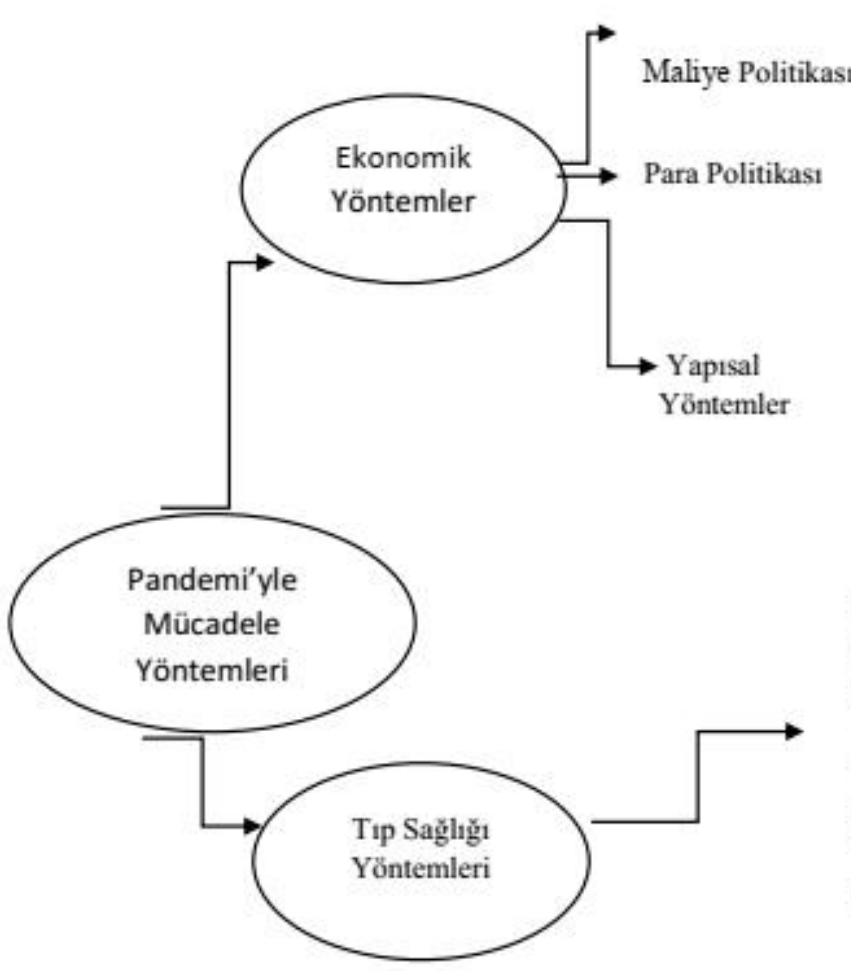

Genişleyici tūketim politikası

Vergi indirimleri ve serbestisi

Doğrudan gelir destekleri

Parafiskal kolayliklar

Para arzında genişlemeler

Kredi faiz indirimi ve kolaylıkları

Banka faiz indirimleri

Sektörel bazda doğrudan fonlama

Esnek imalat sistemleri

Teknolojik üretim platformları

Şekil 3. Pandemi Sürecinde Türkiye'de Alınan Tedbirler

Kaynak: Uluslararası İlişkiler ve Stratejik Araştırmalar (ULİSA) Enstitüsü, 2020:3.

\section{Covid-19 Sürecinde Türkiye'de Uygulanan Ekonomi Politikaları}

Covid-19 salgını ile ülkemizde; ekonomik anlamda uygulanan önlemler genel olarak para ve maliye politikaları başlıkları altında değerlendirilmiştir. 


\subsection{Covid-19 Sürecinde Türkiye'de Uygulanan Para Politikaları}

Tüm dünya ülkelerinde olduğu gibi Türkiye'de pandemi hastalığının ekonomik sarsıntısını azaltmak için ekonomik önlemler kapsamında öncelik para ve maliye politikasına verilmiş, ardından doğrudan gelir destekleri, sektörel destekler ve diğer gelir artırıcı politikalar ile desteklenmiştir. Ülkemizde korona virüse bağlı gelişmelerin Türkiye ekonomisine olumsuz etkilerini sınırlandırmak kapsamında; finansal piyasaların, kredi kanalının ve firmaların nakit akışının sağlıklı bir şekilde devamlılığının sağlanması amacıyla Merkez Bankası 17 Mart 2020 tarihinde yapmış olduğu Para Politikası Kurulu toplantısı ile politika faiz oranını 100 baz puan indirerek $\% 9.75$ seviyelerine düşürmüştür.

Merkez Bankası tarafindan 17 Mart 2020 tarihinde 2020-16 sayılı basın toplantıs1 kapsamında korona virüs salgının küresel çapta ortaya çıkarttığı belirsizliği Türkiye ekonomisi üzerindeki olası olumsuz etkilerinin sınırlandırılması amacıyla; gerek bankaların Türk lirası ve yabancı para likidite yönetiminde esneklik sağlanarak öngörülebilirliğin artırılması ve reel sektöre kredi akışının devamı için bankalara likidite imkanı tanınması gerekse reeskont kredi düzenlemeleri ile ihracatçı firmaların nakit akışının desteklenmesine yönelik bazı önlemler alınmıştır. Alınan önlemleri şu şekilde sıralamak mümkündür (Türkiye Cumhuriyet Merkez Bankası, 2020):

- Merkez Bankası imkânları ölçüsünde bankaların ihtiyaç duydukları likidite ihtiyacını karşılayacaktır.

- Merkez Bankasının haftalık repo ihalesi ihtiyaç olması halinde 91 gün vadeye kadar uzatılarak piyasanın likidite ihtiyacı karşılanacaktır. İhtiyaç duyulması halinde repo ihalelerini kazanan tekliflerden bir kısmı veya tamamı haftalık repo işlemlerinde olduğu gibi bankalar tarafindan ihtiyaç duyulması halinde vadeli repo yerine aynı vade faiz oranı ile Bankalar arası Para Piyasasında depo işlemi olarak sonuçlandırılması sağlanacaktır.

- Hazine'nin 2020 yılı Piyasa yapıcı faaliyet listesinde yer alan bankalara Açık Piyasa İşlemleri (APİ) kapsamında verilen likidite miktarı yükseltilmiştir.

- 30,90 ve 180 gün vadeli ABD doları karşı1lığı swap ihalelerin devamına, gerektirdiği taktirde bu ihalelerin Euro ve altın karşıllı̆̆ olarak ta düzenlenebileceği kararı alınmıştır.

- Reel kredi büyüme koşullarını sağlayan bankalar için zorunlu yabancı para karşılıklar oranı, vade şartı aranmaksızın 500 baz puan indirilmesi sağlanarak koşulları sağlayan bankalara yaklaşık 5.1 milyar ABD \$ karşıllı̆̆ döviz ve altın cinsi likidite verilmesi hedeflenmiştir.

- Reel sektöre kredi nakit akışını sağlamak amacıyla bankalara hedefler sunulmuştur. Hedefi gerçekleştiren bankalara ek likidite garantisi verilmiştir. Bankaların yeni likidite olanaklarından alabilecekleri azami fon tutarı reel sektöre sağladıkları ve sağlayacakları kredi tutarları ile ilişkilendirilecektir. Bu imkânların toplam tutarın, sistemin fonlama ihtiyacının \%25'i sınırlı kalması öngörülmektedir. Bu bağlamda, 91 gün vadeye kadar repo ihaleleri yolu ile Merkez Bankası politika faiz oranı olan bir hafta vadeli repo ihale faiz oranının 150 baz puan altında faiz oranı üzerinden miktar ihalesi yöntemiyle Türk lirası likidite sağlanacaktır. Bu ihalelerde kazanan tekliflerin tamamı veya bir kısmı bankalar tarafından talep edilmesi durumunda aynı şartlar altında Bankalar arası Para Piyasasında depo işlemi olarak sonuçlandırılacaktır. Miktar ihalesi yöntemiyle 1 yıl vadeli döviz karşılığ Türk lirası swap ihaleleri düzenlenecektir. Swap ihaleleri ilgili bankalara Merkez Bankası politika faiz oranı olan bir hafta vadeli repo ihale faiz oranının 100 baz puan altında faiz oranı üzerinden ABD doları, Euro veya altın karşılığı Türk lirası likidite sağlanacaktır. 
- Pandeminin küresel ekonomi üzerindeki olumsuz etkisinin, reel sektör firmalarına bulaşmasını önlemek için ihracat ve döviz kazandırıcı hizmetler reeskont kredilerine yönelik önlemler alınmıştır. Bu kapsamda; Vadesi 18 Mart 2020 tarihinden 30 Haziran 2020 tarihine kadar olan reeskont kredisi geri ödeme süreleri 3 ay uzatılmıştır. Kredi kullanan işletmeler, kredi kullandıkları aracı bankalardan herhangi bir geri ödeme yapmadan mevcut senetlerinin vadesini 3 ay erteleme imkânı sağlanmıştır. Kredi erteleme kapsamında 7,6 milyar ABD doları karşıllı̆ı kadar reeskont kredisinin ötelenmesi imkanı sağlanmıştır. Mevcut kredi taahhüdü açık olan reeskont kredileri ile 18 Mart-30 Haziran 2020 tarihine kadar kullanılacak reeskont kredileri için 1 y1l ilave kapama süresi verilmiştir. Bu ek süre ile birlikte reeskont kredilerin taahhüt kapsamı 24 aydan 36 aya uzatılmıştır. Hali hazırda kullanılan reeskont kredilerinin azami vadeleri, 20 Mart 2020 tarihinden geçerli olmak üzere, kısa vadeli reeskont kredilerin kullanım süresi 120 günden 240 güne, uzun vadeli krediler için 720 güne uzatılmıştır.

Korona virüsün ekonomik ve finansal etkilerine karşı alınan ilave tedbirlere ilişskin 31 Mart 2020 tarihli duyuruda, 2020 yılı Para ve Kur Politikası metninde belirlenmiş limitler çerçevesinde yürütülen Açık Piyasa İşlemleri (API) portföyü doğrudan alım işlemlerinin önden yüklemeli olarak gerçekleştirilebileceği ve gerektiğinde söz konusu limitlerin piyasa koşullarına göre güncellenebileceği açıklanmıştır. Ayrıca, geçici bir süre için Piyasa Yapıcı bankalara sağlanan, İssizlik Sigortası Fonu'ndan satın aldıkları DIBSS'leri TCMB tarafindan belirlenen koşullar ve tutarlar dâhilinde TCMB'ye satma imkânı kapsamında yapılan alımların, bu limitlerin dışında değerlendirileceği belirtilmiştir. Bu çerçevede, piyasa derinliğinin korunması, para politikası aktarım mekanizmasının güçlendirilmesi ve Piyasa Yapıcılı̆̆ sisteminin desteklenmesi amacıyla aşağıdaki ilave önlemler alınmıştır (Türkiye Cumhuriyet Merkez Bankası, 2020):

- 2020 yılı Para ve Kur Politikası metninde 2020 yılı için TCMB analitik bilanço aktif toplamının azami \% 5'i olarak belirlenmiş olan APİ portföyü nominal büyüklüğünün TCMB analitik bilanço aktif toplamına oranı azami \% 10 olarak yeniden belirlenmiştir.

- Finansal piyasaların işleyişine ve para politikası aktarım mekanizmasına sağladığı katkıların devamını sağlamak için Piyasa Yapıcı (PY) bankalara tanınan TCMB'ye DİBS satım imkânında değişiklik yapılmıştır. Bu bağlamda; a. PY bankalara tanınan TCMB'ye doğrudan DİBS satım imkânına ilişkin limitlerin, repo işlem limitlerinden bağımsız olarak değerlendirilmesine ve PY bankaların repo işlem limitlerine eşit miktarda DİBS satım limiti tanımlanmasına, b. Söz konusu alımların da APİ portföyü için belirlenen azami \% 10'luk toplam limit çerçevesinde gerçekleştirilmesine, c. Bu çerçeve dahilinde alımı gerçekleştirilecek DİBS'lerin ve alım miktarlarının TCMB tarafından belirlenmesine, $d$. Alımların açılacak miktar ihaleleri yoluyla gerçekleştirilmesine karar verilmiştir.

\subsection{Covid-19 Sürecinde Türkiye'de Uygulanan Maliye Politikaları}

Korona virüs salgını nedeni ile ekonomide hem talep hem de arzın etkilenmesi nedeniyle zor bir döneme girilmiş bulunmakta. Bu kapsamda ülkemizde, korona virüs salgınının olumsuz etkilerini sınırlandırmak ve yaşanılan sürecin ekonomiye, piyasaya, üretime, istihdama olumsuz etkilerini azaltmak amaciyla 18 Mart 2020 tarihinde "Ekonomik İstikrar Kalkanı" adlı paketle 100 milyar liralık bir kaynak seti devreye sokulmuştur. 19 maddeden oluşan paketin genel içeriğini şu şekilde sıralamak mümkündür (Türkiye İhracatçllar Meclisi, 2020: 1-28):

- Perakende, Otomotiv, Ulaştırma, AVM, Demir-Çelik, Sinema-Tiyatro, Otel-Konaklama, Yiyecek-İçecek, Konfeksiyon-Tekstil ve Organizasyon sektörleri için Muhtasar 
Beyanname, KDV ve SGK primlerinin Nisan, Mayıs ve Haziran ödemeleri 6 ay süreyle ertelenmiştir.

- Konaklama vergisi Kasım ayına kadar alınmayacaktır.

- Otel kiralamalarına ilişkin irtifa hakkı bedeli ve hasılat payı ödemeleri Nisan, Mayıs ve Haziran ayları için 6 ay süreyle ertelenmiştir.

- İç havayolu taşımacılığında KDV oranını 3 ay süreyle \% 18'den \% 1'e düşürülmüştür.

- Pandemi sürecinde nakit akış sıkıntısı çeken işletmelerin bankalara olan kredi anapara ve faiz ödemelerini asgari 3 ay ertelenecek ve gerekirse ilave finansman desteği imkânı verilecektir.

- İhracattaki düşüş nedeniyle kapasite kullanım oranı düşen ihracatçı firmalara stok finansmanı desteği sağlanacaktır.

- Pandemi sürecinde işleri bozulması neticesinde kredilerini ödeyemeyen işletmelerin talep etmeleri durumunda Halkbank'a olan kredi borçları ve faiz ödemeleri, Nisan, Mayıs ve Haziran ayı boyunca faizsiz olarak 90 gün ötelenmiştir.

- Kredi Garanti Fonu limiti 25 milyar liradan 50 milyar liraya artırılacaktır. Nakit ihtiyac1 çeken ve teminat açığı bulunan KOBİ'ler ve firmalara kredi önceliği tanınacaktır.

- İhtiyacı olanlar için uygun vade ve koşullarda sosyal amaçlı kredi paketleri hazırlanmıştır. Bu krediler 5.000, 7.500 ve 10.000 lira olup ilk altı ayı ödemesiz 36 ay vadeli düşük faizli kredilerdir.

- Değeri 500.00 bin liranın altında olan konutlar için kredi miktarı \% 80'den \% 90'a yükseltilmiş, asgari peşinat miktarı da \% 10'a indirilmiştir.

- Covid-19 nedeniyle Nisan, Mayıs ve Haziran aylarında temerrüde düşen firmaların kredi sicilinin olumsuz etkilenmemesi için 'mücbir sebep' ibaresi getirilmiştir.

- Asgari ücret desteğinin devamına karar verilmiştir.

- Mevzuatta yer alan esnek ve uzaktan çalışma modellerinin daha işlevsel şekilde kullanilmasi.

- Kısa Çalışma Ödeneğinin devreye sokulmasına karar verilmiştir. Bu sayede işçilere geçici bir gelir desteği imkânı sağlanırken, işverenlerin de maliyet yükü azaltılması hedeflenmiştir.

- Emekli maaşında en düşük miktar 1.500 lira olarak belirlenmiştir.

- Emekli bayram ikramiyesi Nisan ayı başı itibariyla ödenmiştir. Emekli maaş promosyon ödemelerinin de, doğrudan hesaplara yatırılması kararı alınmıştır.

- Aile, Çalışma ve Sosyal Politikalar Bakanlığı tarafında ihtiyaç sahibi ailelere yardım amaçlı ek 2 milyar liralık bir kaynak oluşturulmuştur.

- İstihdamdaki sürekliliği temin etmek amacıyla 2 aylık telafi çalışma süresini 4 aya çıkartılmıştır.

- 80 yaşını geçmiş ve yalnız yaşayan yaşlılar, evde sağlık hizmetleri ve sosyal hizmet kapsamında periyodik takibe alınmıştır.

\section{Sonuç ve Değerlendirme}

Korona virüs salgını, tıbbi açıdan dünya ülkelerinin büyük bir çoğunluğuna bulaşmış olmasına rağmen ekonomik ve finansal yönden tüm dünya ülkelerini ve sektörleri olumsuz etkilemiştir. Covid-19 salgını dünya üzerinde yavaşlamış fakat hastalık tamamen sona erdirilememiştir. Hastalığın ikinci bir dalga ile dünya ülkelerine tekrar yayılıp yayılmayacağı bilim 
insanları tarafından tartışılmaktadır. Belirsizlik her geçen gün ülke ekonomilerini olumsuz etkilemektedir. Salgın devam ettiği için, ekonomik maliyet tahmini yapmak mümkün değildir. Fakat Covid-19 salgını bir gerçeği ortaya çıkarmıştır; dünya ülkeleri salgına karşı önce sağlıklı bir toplum düzenini tekrar inşa etmek adına birlikte mücadele etmeli daha sonra hızlı bir şekilde ekonomilerini rayına oturtmaları gerekmektedir. Bu amaçla genelde dünya ülkeleri için özel de Türkiye için öneriler sunmak mümkündür. Dünya geneli için söz konusu öneriler şu şekilde sıralanabilir:

- Dünya ülkelerinin önceliği sağlıklı bir toplum yapısını oluşturmak olmalıdır. Bu yüzden tüm ülkeler salgınla mücadele programına dikkat etmeli.

- Hastalıkla mücadele kapsamında yer alan tıbbi malzemelerin ithalatında ödenen vergilere hastalık süresi boyunca muafiyet getirilmeli.

- Salgının bulaşmasını kısıtlamak ve tamamen ortadan kaldırmak için ülkeler, evde kalması gereken vatandaşların temel ihtiyaçlarını karşılamalı, zorunlu ödemeleri için doğrudan karşılıksız gelir desteği sağlamalıdır.

- Pandemi sürecinde işsiz kalan vatandaşları için ülkeler, kriz sürecinde ekonomik destek sunmalidirlar.

- Finansal sürecin önemli yapı taşlarından olan bankaların mali sistemlerinde meydana gelen bozulmalardan dolayı destekler verilmelidir.

- Başta KOBİ'ler olmak üzere finansal yapıları bozulmuş olan şirketlerin işleyişlerini devam ettirmeleri için nakit, kredi destekleri sağlanmalı, kredi vade süreleri uzatılmalıdır.

- Ülke Merkez Bankaları parasal genişlemeyi sağlayıcı politikalarla devlete nakit desteği sağlamalıdır. Bu süreçte gerekirse, enflasyonun biraz yükselmesine izin verilmeli ancak ekonominin genel dinamiklerine zarar verilmemeli.

- Zorluk çeken şirketler ve mükellefler için sermaye yapıları düzelinceye kadar vergi muafiyeti sağlanmalıdır.

Dünya ülkeleri için tavsiye edilen salgınla mücadele önerilerin birçoğu Türkiye için de geçerli tavsiyelerdir. Fakat her ülkenin kendine özgü dinamikleri olduğundan alınan tedbir kararlarında da bir takım değişiklikler ve öncelikler olması muhtemeldir. Bu açıdan tüm dünya da geçerli olan tavsiye kararlarına ek olarak, Covid-19 küresel salgın sürecinde, Türkiye için sunulacak öneriler şu şekilde sıralanabilir:

- Dünya ülkeleri için tavsiye edilen önceliklerin başında yer alması gereken insan sağ lığ 1 için gerekli olan sağlık tedbirlerinden taviz verilmemelidir.

- Devlet tarafindan ekonomiye destek programları başta para ve maliye politikası olmak üzere genişletilerek devam ettirilmelidir.

- Devlet ve sivil toplum kuruluşları ile ortak ekonomik platform oluşturmalı, birlikte hareket edilmelidir.

- Diş ticarette ihracat ve ithalat yapan firmalara vergi muafiyeti, KDV indirimi ve iadesi, teşvik, destek primleri, vb. uygulamalarla desteklenmeli.

- İstihdam artırıcı, işsizliği azaltıcı politikalar üretilmeli.

- Covid-19 salgınının Türkiye'de gıda sektöründe bir olumsuzluk oluşturmaması için esnek üretim modeline geçilerek gıdadan, sağlığa birçok sektörde ihracat artırılabilir.

- Covid-19 salgını sürecinde, Türkiye'nin sağlık sektöründeki başarısı, sağlık turizmine daha fazla önem vermesi gerekliliğini ortaya koymuştur.

- Covid-19 süreci boyunca, tüm Dünya ülkelerinde Çin mallarına karşı bir tepki oluştuğu görülmektedir. Çin'in dünya ihracatında oldukça iyi bir pazar payına sahip 
olduğu göz önüne alındığında, bu pazarı kaybetmesi durumunda bu süreçte genç ve dinamik nüfuz yapısı, coğrafi konumu ve ulaşım imkânlarına sahip olan Türkiye'nin dünya ticaretinde üst sıralara yerleşmesi mümkündür.

\section{Kaynakça}

African Union (2020). Impact of the Coronavirüs (Covid-19) on the African Economy. 1-35. https://au.int/sites/default/files/documents/38326-doc-covid

19_impact_on_african_economy.pdf Erişim Tarihi: 30.04.2020.

Baldwin, R. (2020). The supply side matters: Guns versus butter, COVID-style”, VOX CEPR Policy Portal, Erişim Tarihi: 05.06.2020.

Duran, H. (2020), "Devletlerin korona virüsle karşılaştırmalı mücadele stratejileri”, Siyaset, Ekonomi ve Toplum Araştırmaları Vakfi (SETA), Nisan 2020, Sayl: 317. 1-26.

Düşündere Taşöz, A. \& Dündar, M. (2020). Covid-19'un Türkiye ekonomisine etkisini nasıl takip edebiliriz. Türkiye Ekonomi Politikaları Araştırma Vakfi (TEPAV), Değerlendirme Raporu, Mart2020,https://www.tepav.org.tr/upload/files/1584894165-3.N202005_COVID _19un_ Turkiye_Ekonomisine_Etkisini_ Nasil_Takip_Edebiliriz.pdf Erişim Tarihi: 07.06.2020. https://doi.org/10.14783/maruoneri.677425

Economic and Social Commission for Asia and the Pacific (2020). The Impact and Policy Responses for COVID-19 in Asia and the Pacific. 1-32. https://www.unescap . org/sites/default/files/COVID\%20_Report_ESCAP.pdf. Erişim Tarihi: 30.04.2020.

HSBC Global Research (2020). Dünya ve belli belirgin ülkeler için enflasyon ve büyüme tahminleri. https://www.research.hsbc.com/ibcom/out/ibcom/internal/. Erişim Tarihi: 05.06.2020.

International Labour Organization (2020). COVID-19 andtheworld of work: Impactandpolicyresponses. 1-15. https://www.ilo.org/wcmsp5/groups/public/---dgreports/ ---dcomm/ documents/briefingnote/wcms _ 738753.pdf (Erişim Tarihi: 26.04.2020).

International Monetary Fund (2020).G-20 Surveillance Note. Covid-19-Impact and Policy Consideration. G-20 Finance Ministers and Central Bank Governors' Meetings April 15, 2020 Virtual Meeting. 1-15. https://www.imf.org/ external/np/g 20/pdf/2020 /041520.pdf Erişim Tarihi: 01.05.2020.

Loayza, N.V.,\&Pennings, S. (2020). Macroeconomic policy in the time of covid-19: A primer for developing countries. World Bank: Washington DC. http:// documents.worldbank.org/cu rated/en/951811585836124198/pdf/Macroeconomic-Policy-in-the-Time-of-COVID-19-APrimer-for-Developing-Countries.pdf. Erişim Tarihi: 05.06.2020.https://doi.org/10.1596 133540

Mishra, K. M. (2020). The World after COVID-19 and its impact on global economy. Econstor, 112.https://www.econstor.eu/bitstream/10419/215931/1/MKM\%20PAPER\%20FOR\%20C OVID .pdf (Erişim Tarihi: 04.06.2020).

Ozili, P.,\& Arun, T. (2020). Spillover of COVID-19: impact on the global economy. SSRN Electronic Journal, 1-27. https://dx.doi.org/10.2139/ssrn.3562570.

Türkiye Bilimler Akademisi (2020). Covid-19 pandemi değerlendirme raporu", Muzaffer Şeker ve Diğ..

Türkiye Cumhuriyet Merkez Bankası (2020). Koronavirüsün Ekonomik ve Finansal Etkilerine Karş1 Alınan İlave Tedbirlere İlişkin Basın Duyurusu (2020-2021) https://www.tcmb.gov.tr 
/wps/wcm/connect/tr/tcmb+tr/main+menu/duyurular/basin/2020/duy2020-21. Erişim tarihi: 04.06.2020. https://doi.org/10.14784/jfrs. 87278

Türkiye İhracatç1lar Meclisi (TIMM), (2020), "14 Nisan 2020 itibariyle COVID-19 ile mücadele için ülkemizde alınan tedbirler", Nisan 2020, İstanbul. https://www.tim.org.tr/files/downloads/ Koronavirus_Dosyasi/TIM_Ekonomik_Istikrar_Kalkan\%C4\%B1_Tedbirleri_14.04.2020.p dfErişimTarihi: 13.06.2020. https://doi.org/10.1063/10.0000237

Türliye Bilimler Akademisi (TUBA), (2020), "Covid-19 Pandemi Değerlendirme Raporu”, Nisan, 2020, Ankara. http://www.tuba.gov.tr/files/images/2020/kovidraporu/ Covid19\%20Raporu-Final+.pdf Erişim Tarihi: 05.06.2020.

Uluslararası İlişkiler ve Stratejik Araştırmalar (ULİSA) Enstitüsü. (2020), Kovid-19 (Koronavirüs) salgınının ekonomik etkileri. Nisan 2020, Sayı: 1.

Voyvoda, E. \&Yeldan, E. (2020). COVID-19 salgının Türkiye ekonomisi üzerine etkileri ve politika alternatiflerinin makroekonomik genel denge analiz. Mayıs 2020, Ankara http://cloudsdomain.com/uploads/dosya/41711.pdf Erişim Tarihi: 11.06.2020. https://doi.org/10.24181/tarekoder.701649

World Health Organization (WHO) (2020). Coronavirus disease (COVID-19) Situation Report 136. https://www.who.int/docs/default-source/coronaviruse/situation-reports/20200604covid-19-sitrep-136.pdf?sfvrsn=fd36550b_2 Erişim Tarihi: 05.06.2020.

Yorulmaz, R. \& Kaptan, S. (2020). Kovid-19 ile mücadele sürecinde maliye politikalarının rolü. Editör: İbrahim Demir, Uluslararası İlişkiler ve Stratejik Araştırmalar (ULISA) Enstitüsü, Nisan 2020, Sayı: 1. 